\title{
Attitudes towards genomic. Research in four Latin American countries
}

\author{
Eduardo Rodríguez Yunta* \\ Centro Interdisciplinario de Estudios en Bioética \\ Universidad de Chile \\ Avda. Diagonal Paraguay 265, Piso 8 \\ Santiago, Chile \\ Tel: 5632 678-2539 \\ Fax: 56326782254 \\ E-mail: rodrigue@chi.ops-oms.org
}

Carolina Valdebenito Herrera

Centro Interdisciplinario de Estudios en Bioética

Universidad de Chile

Avda. Diagonal Paraguay 265, Piso 8

Santiago, Chile

Tel: $5632678-2539$

Fax: 56326782254

E-mail: cvaldebenito@chi.ops-oms.org

\section{Adelio Misseroni}

Centro Interdisciplinario de Estudios en Bioética

Universidad de Chile

Avda. Diagonal Paraguay 265, Piso 8

Santiago, Chile

Tel: $5632678-2539$

Fax: 56326782254

E-mail: amisseroni@colegiomedico.cl

Lautaro Fernández Milla

Servicio de Salud Metropolitano Sur

Santiago, Chile

E-mail: lautarofermi@ssms.cl

Delia Outomuro

Facultad de Medicina

Universidad de Buenos Aires Argentina

E-mail: doutomuro@fmed.uba.ar

Irene Schiattino Lemus

Escuela de Salud Publica

Universidad de Chile Santiago, Chile

E-mail: ischiattino@med.uchile.cl

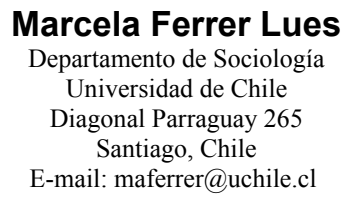

Fernando Lolas Stepke

Centro Interdisciplinario de Estudios en Bioética

Universidad de Chile

Avda. Diagonal Paraguay 265, Piso 8

Santiago, Chile

E-mail: flolas@uchile.cl

http://www.uchile.cl/bioetica/

Financial support: Research funded by grants from U.S. Department of Energy award DE-FG02-02R 63435 and also through fellowships to students of the International Program of Ethics of Biomedical and Psychosocial Research, supported by Fogarty NIH Research Grant \#D43 TW 06056.

Keywords: cloning, genome, social representations, transgenic.

*Corresponding author 
The present reflection refers to data obtained about the social representations of genomic research and its applications through interviews with legislators and lawyers, biomedical researchers and civilians and the review of scientific and legal literature in four Latin American countries: Argentine, Chile, Mexico and Peru.

Several issues are addressed: little access to prevention and therapeutic methods, lack of equity in health benefits, commercialization of gene sequences through patents which leads to commercial exploitation of underdeveloped countries, the possibility of physical or psychological damage or genetic discrimination, the possibility of genetic modifications or abortion for eugenic reasons, the necessity of safeguarding confidentiality, risks and benefits of the use of transgenics and cloning, the necessity of legal regulation to prevent the pathway towards genetic enhancement or reproductive human cloning and of regulating access to genetic information.

Using the method of content analysis of verbal behaviour to evaluate the degree of anxiety and hostility of subjects in relation to the Human Genome Project (HGP) developed by Gottschalk and Gleser, an inverse relation between levels of anxiety and level of knowledge was observed which highlights the importance of educating the population. Differences in the level of hostility towards the HGP were also found among the groups.

In the year 2001, the Human Genome Project has achieved one of the greatest landmarks in the science of genetics, the complete sequence of the human genome. Investigation continues as many genes still remain to be characterized and the function of others still needs to be studied.

There are great expectations regarding the social applications on health of genomic information. Many genes are related to hereditary diseases, 1112 genes related to Mendelian inheritance diseases have been identified (OMINM, Catalogue of Mendelian Inheritance Diseases). Many others are involved in multifactorial diseases, such as cancer or diabetes. The possibility of knowing the genetic constitution of individuals opens a range of ethical, legal and social issues. Persons can be characterized by their genes and DNA sequence which can give information, for instance on paternity and health status, making them susceptible to discrimination and stigmatization (for example: stereotyping, showing prejudice, increasing health insurance fees, avoiding hiring someone by employers).

Along with the human genome, under the auspice of the project, several living organisms' genomes have been sequenced and others are under way (http://www.ornl.gov/sci/techresources/Human_Genome /vl_organisms.shtml). The rationale to study some of these living organisms is to use them as models for fighting infections by making them more resistant, or studying diseases and for developing genetically modified organisms to improve crops and cattle.

In general, there is an impression that Latin American countries are not prepared to respond to the development of genomics and genetic engineering which has taken place in developed countries. There is almost no interest from the governments for research in this area since they have more urgent priorities. As a result, Latin American countries act mostly as consumers resulting in little information being transmitted to lay civilians and a lack of legal norms to regulate this field in general. This contributes to the generation of certain anxiety since there are fears that certain issues raise by the expansion of genomic research, such as genetic modifications, could be manipulated and used for the interest of a few.

The present reflection is based both on data on the social representations of genomic research and its applications obtained through interviews with scientists, legislators, lawyers, student from journalism and engineering careers and civilians in four countries: Argentine, Chile, Mexico and Peru and on data originating from the biomedical and legal literature in these countries (Lolas et al. 2004). The issues raise by genomic research can have major social, legal, political, economical and cultural repercussions which can involves not only specialists but lay people as well.

\section{MATERIALS AND METHODS}

This study is part of a project supported by the U.S. Department of Energy (Grant DE-FG02-02ER63435), which includes interviews and questionnaires to biomedical researches on genomics $(n=81)$, legislators and lawyers with knowledge on legal aspects related to genetics $(\mathrm{n}=$ $60)$, students from journalism and engineering careers $(\mathrm{n}=$ $85)$ and civilians no specialists on genomics $(n=85)$ with respect to the social applications and representations of the human genome project in the four Latin American countries. These data are complemented with bibliographical analysis of papers that were published in the four countries. The interviews cover the following range of issues: possible benefits, negative consequences and regulatory measures and transmission of knowledge to the general population with respect to the human genome project (Table 1); possible benefits, negative consequences and regulatory measures to cover with respect to human cloning (Table 2); possible benefits, negative consequences and regulatory measures to cover with respect to the use of transgenics (Table 3); acceptance or refusal to participate in genomic research as subjects (Table 4). Data gathered from the interviews are compared with the frequency with which appear the same topics and lines of reasoning in the scientific literature to provide a reference for the extent of its influence (Table 1, Table 2, Table 3 and Table 4). Level 


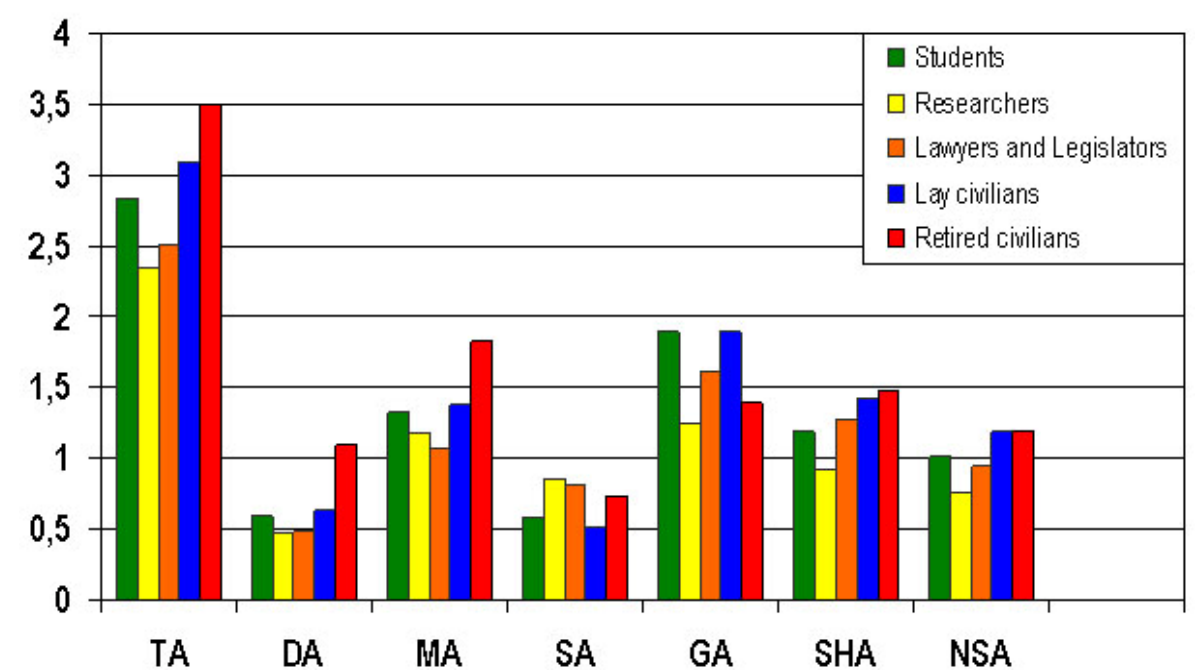

Figure 1. Level of anxiety observed with the topics related to genomic research and its social applications in the different groups.

$\mathrm{TA}=$ Total anxiety; DA = Death anxiety; MA = Mutilation anxiety; SA = Separation anxiety; GA = Guilt anxiety; SHA = Shame anxiety; NSA = Non specific anxiety.

of knowledge of respondents is evaluated by a questionnaire about basic issues of genomic research (sequencing, Latin American contribution, genes identified, bioinformatics, biochips, genomic medicine, gene therapy, genetic mutations, genetic tests, transgenic and cloning) and legal norms (1997 UNESCO Declaration, Latin American legislation, European legislation).

The semi-structured interviews are analyzed through the content analysis of verbal behaviour to evaluate the degree of hostility and anxiety of subjects in relation to the Human Genome Project according to the method of Gottschalk and Gleser (Gottschalk and Lolas, 1989). This procedure uses sentences or grammatical clauses as unit of codification with precise rules for computing words and for making psychologically relevant inferences, based upon the notion that speech reflects feeling states and that these could be qualitatively and quantitatively operationalized in terms of textual or speech markers; these units of codification are later assigned to a system of categories, theoretically defined, with a quantity assigned according to the intensity and personal participation of the individual. It is possible to content-analyze the meaning of not only conventional dictionary-derived words, but also idiomatic and slang expressions that are not defined in ordinary dictionaries which the user is capable of understanding and defining. The frequency of occurrence of any content category can be corrected for the number of words uttered, namely content category per 100 words. It provides mathematical transformations of scores that make their frequency distribution parametric, which allows the application of statistical procedures for data assessment.

Content analysis helps to elucidate the genuine subjective state of the individual even when words are used to hide mental experiences or to deceive. The method use psychoanalytic insights in its affect scales for anxiety and hostility by including displacement and denial of these affects among the verbal categories counted. Negative emotions, such as anger, guilt, shame, hostility or fear, can be measured with this method so that reactions related to stereotyping and prejudice can be quantified. The anxiety scale measures the following fears: death, mutilation, separation, guilt, shame and non specified fears. Fear of death is assessed by those content items dealing directly with death and destruction (for example, issues raise by eugenesia and biological war). The descriptive items for mutilation and separation anxiety are derived from psychoanalytic psychology. Mutilation refers to physical damage (for example, issues raise by having genetic diseases or health damages inflicted by genetic manipulations). Separation includes desertion, lack of support, abandonment, loneliness, feeling unloved (for example, issues raise by lack of equity in access to genomic medicine, lack of governmental support for genetic research, lack of legal regulation for genomics) The descriptive items differentiating shame from guilt anxiety define shame through verbal references to ridicule, feelings of inadequacy, embarrassment, humiliation, and exposure of shortcomings or details of an individual's private life (for example, issues raise by lack of knowledge on genomic issues or privacy of genetic data). Guilt is defined through verbal references to adverse criticism, abuse, condemnation, or moral disapproval, especially based on internalized attitudes or values (for example, issues raise by moral disapproval of genetic modifications, eugenesia or cloning). Diffuse or nonspecific anxiety is the subtype of anxiety for which it is impossible to distinguish the type of anxiety or fear that is being verbalized (for example, fear 


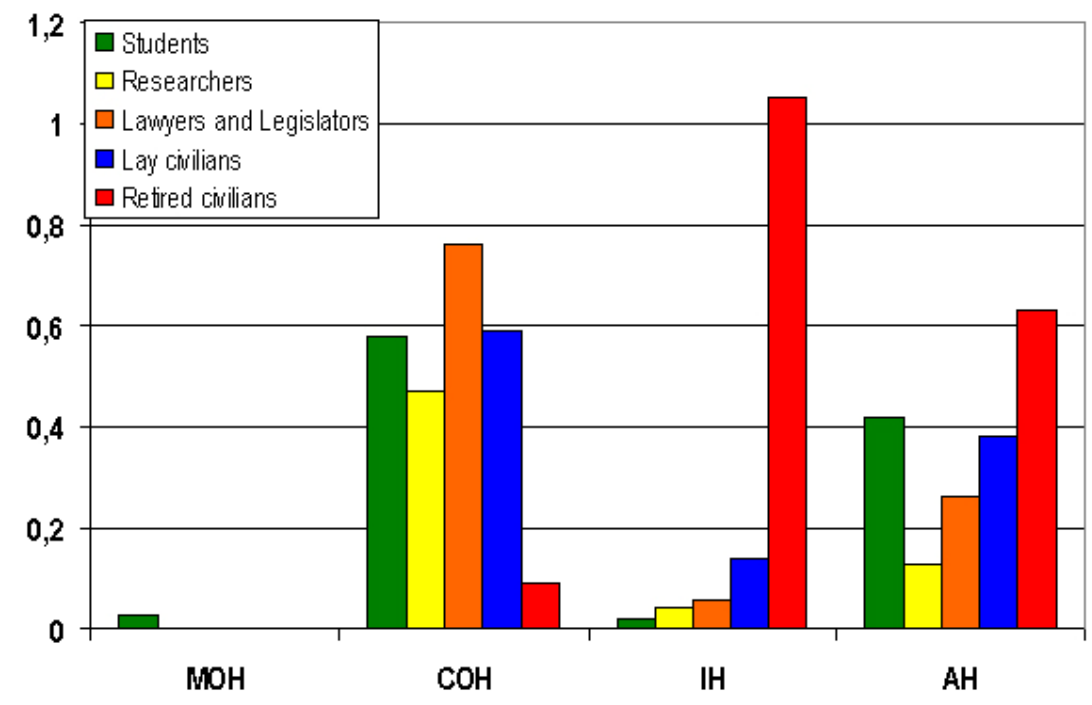

Figure 2. Level of hostility originated by the topics related to genomic research and its social applications in the different groups.

$\mathrm{MOH}=$ Manifest Outer Hostility; $\mathrm{COH}=$ Covered Outer Hostility; $\mathrm{IH}=$ Inner Hostility; $\mathrm{AH}=$ Ambivalent Hostility.

towards genomic issues without specific reference). This anxiety scale measures the magnitude of anxiety being experienced (subjective level) but do not register completely unconscious anxiety.

The hostility scale measures the following aggressive behaviours: those done by one to others (manifest outer hostility), those made by others to others (covered outer hostility), those made by one towards oneself (inner hostility), those made by others to oneself (ambivalent hostility).

A score is obtained for anxiety and hostility scale by multiplying the number of scorable clauses by the weights assigned to each verbal category, dividing the sum of these products by the total number of words in the speech sample, and multiplying the quotient by 100 to give an index of the amount of each psychological dimension per 100 words. For assigning scores, these are higher when the person who speaks is involved (higher emphasis gives one point more) followed by references to others, followed by references to objects or denial. Scores are corrected by adding 0.5 to each raw score and dividing the sum by the number of words spoken, multiplying by 100 , and obtaining the square root of the product.

\section{RESULTS}

Table 1, Table 2, Table 3 and Table 4 present the qualitative answers tabulated when they appear in more than $10 \%$ of the sample. Groups are categorized according to degree of knowledge on the topic of genomics. Biomedical researches were identified as the group more knowledgeable on the issues addressed, followed by legislators and lawyers, students and lay civilians. Table 1 shows the frequency of appeal to benefits (treatmentdiagnosis, prevention), negative consequences (genetic enhancement, instrumentation, inequity, commercialization, genetic discrimination, playing God's role, eugenics) and needs to cover (lack of research support, regulation, privacy and lack of information) with respect to the human genome project in the interviews and in the biomedical and legal articles. Table 2 shows the frequency of appeal to benefits (organ transplantation), negative consequences (loss of singularity, instrumentation, damage to health, playing God's role, being artificial or having behavioural problems) and needs to cover (regulation or prohibition) with respect to human cloning in the interviews and in the biomedical and legal articles. Table 3 shows the frequency of appeal to benefits (enhancement of production and properties, plague resistance) negative consequences (cancer induction, alteration ecological equilibrium, biodiversity diminution, commercialization, damages to health, being artificial) and needs to cover (biosecurity, regulation) in relation to the use of transgenics in the interviews and the biomedical and legal articles. Table 4 shows the frequency of appeal to acceptance (for treatment, enhancement, science advancement) or rejection (treated as Guinea pig, not having been tested, going against Nature, fear to the unknown, acceptance of oneself or not needing change and fear to health damage) to participate in genomic research as subject in the interviews. In the scales of anxiety and hostility (Figure 1 and Figure 2) a subgroup was created for lay retired civilians, which appear to have the lesser knowledge in genomics.

Biomedical researchers appreciate more the benefits of the human genome project, but they see or experience the lack of governmental support for research (Table 1). University students worry about the lack of equity in access to 
genomic medicine in the population and the instrumentation of human beings (Table 1). Lawyers and legislators are worried about the regulation of genetic information because of its possible manipulation by power interests, of possible eugenic selection of embryos and of possible genetic discrimination by health insurers and employers (Table 1). Commercialization of genetic products for agriculture, for example, is seen as negative by all groups since it will benefit mostly the international biotechnological companies and not local farmers.

In general, human reproductive cloning is negatively valued by all groups, being associated with lost of singularity for clones, since they will be genetically identical to their parental nucleus; a form of manipulation or using human beings as means to an end (role in society defined before the clone is born); as a source of power by using clones for example for war or as servants; or as altering human behaviours making clones more aggressive or having psychological problems (Table 2); some lawyers and legislators see it as an instrument of power which should be prohibited since certain genotypes would be chosen by those who take decisions using clones for purposes such as war or as means for an end, while others consider that it needs to be regulated. Among lay civilians, influenced by media portray, it is spread the uncritical believe that a human clone does not have a soul because it would be a replication of a being already in existence and that a clone is a exact copy of a person including his/her personality and conscience. Lay civilians fear that genetic manipulation may take away God's role in human creation since new babies would be design according to human will not by natural means (Table 1 and Table 2). However, therapeutic cloning is seeing as beneficial for its potential in organ transplantation by some (Table 2).

Biomedical researches see benefits in the generation of transgenics for increasing productivity and enhancement of properties for cattle and agriculture, such as vigour, duration, nutrition and plague resistance (Table 3). Lay civilians and university students tend to consider genetically modified organisms as dangerous for health, specially of inducing cancer and as artificial which is equated to lack of trustworthiness for consuming them (Table 3).

What is written in legal and biomedical articles is similar to the data gathered through interviews with lawyers and researches. Lay civilians, on the other hand, seems not to be influenced much by the scientific literature, they rather

Table 1. Consequences of the use of genetic information.

\begin{tabular}{|c|c|c|c|c|c|c|}
\hline Issue & $\begin{array}{l}\text { Lawyers } \\
\qquad(n=58)\end{array}$ & $\begin{array}{l}\text { Legal } \\
\text { articles } \\
(n=49)\end{array}$ & $\begin{array}{l}\text { Lay Civilians } \\
\qquad(n=76)\end{array}$ & $\begin{array}{l}\text { Students } \\
\qquad(n=77)\end{array}$ & $\begin{array}{l}\text { Scientists } \\
\qquad(n=74)\end{array}$ & $\begin{array}{c}\begin{array}{c}\text { Biomedical } \\
\text { articles }\end{array} \\
(n=127)\end{array}$ \\
\hline Treatment-Diagnosis \% & 48 & 77 & 45 & 60 & 91 & 74 \\
\hline Prevention \% & 19 & 22 & 8 & 10 & 26 & 18 \\
\hline $\begin{array}{l}\text { Enhancement (beauty, } \\
\text { intelligence) } \%\end{array}$ & 16 & 4 & 9 & 14 & 15 & 12 \\
\hline Instrumentation (power) \% & 21 & 16 & 16 & 12 & 18 & 7 \\
\hline Inequity \% & 28 & 8 & 9 & 12 & 22 & 10 \\
\hline Commercialization \% & 22 & 39 & 8 & 7 & 11 & 14 \\
\hline Discrimination \% & 45 & 49 & 7 & 4 & 23 & 20 \\
\hline God's role \% & 0 & 0 & 11 & 5 & 0 & 2 \\
\hline Eugenics \% & 10 & 24 & 0 & 0 & 4 & 17 \\
\hline Lack of research support \% & 2 & 0 & 1 & 4 & 62 & 5 \\
\hline Regulation necessity\% & 66 & 78 & 5 & 0 & 18 & 17 \\
\hline Privacy \% & 29 & 76 & 1 & 3 & 12 & 12 \\
\hline Lack of information \% & 14 & 0 & 11 & 9 & 3 & 0 \\
\hline
\end{tabular}


Table 2. Perceived effects of human cloning.

\begin{tabular}{|l|c|c|c|c|c|c|}
\hline \multicolumn{1}{|c|}{ Issue } & $\begin{array}{c}\text { Lawyers } \\
\text { (n=58) }\end{array}$ & $\begin{array}{c}\text { Legal } \\
\text { articles } \\
\mathbf{( n = 4 9 )}\end{array}$ & $\begin{array}{c}\text { Lay } \\
\text { Civilians } \\
\mathbf{( n = 7 6 )}\end{array}$ & $\begin{array}{c}\text { Students } \\
\mathbf{( n = 7 7 )}\end{array}$ & $\begin{array}{c}\text { Scientists } \\
\mathbf{( n = 7 4 )}\end{array}$ & $\begin{array}{c}\text { Biomedical } \\
\text { articles } \\
(\mathbf{n = 1 2 7})\end{array}$ \\
\hline Organ transplants \% & 28 & 73 & 26 & 39 & 42 & 74 \\
\hline Singularity loss \% & 6 & 45 & 14 & 17 & 4 & 31 \\
\hline Instrumentation (power) \% & 31 & 18 & 17 & 17 & 17 & 16 \\
\hline Health damage \% & 0 & 9 & 5 & 14 & 13 & 10 \\
\hline God's role \% & 3 & 0 & 22 & 17 & 0 & 0 \\
\hline Artificial \% & 16 & 0 & 9 & 1 & 0 & 0 \\
\hline Behaviour problems \% & 11 & 36 & 13 & 5 & 0 & 16 \\
\hline Regulation necessity\% & 13 & 0 & 4 & 4 & 8 & 10 \\
\hline Prohibition \% & 41 & 64 & 0 & 1 & 8 & 26 \\
\hline
\end{tabular}

tend to rely on what they hear and see in the media.

With respect to participating in genomic research as subjects most respondents would accept to be enrolled in a study when the study has a therapeutic component, maybe because it has a chance to benefit them (Table 4). Researches are interested as well in scientific advancement and would accept more genetic enhancement for reasons related to beauty and intelligence (Table 4). Reasons given for refusing to participate in genomic research are: fear of instrumentation or being treated as guinea pigs, fear of physical damage, lack of knowledge of what it means to be a research subject, acceptance of oneself with his/her weaknesses so that no change in genetic content is necessary, or lack of previous studies being made on humans (Table 4).

Figure 1 presents the levels of anxiety observed using the Gottschalk and Gleser method. There is an inverse relationship between the level of anxiety and the level of knowledge. The group which produces the greatest level of total anxiety is that of the retire lay civilians who have very little knowledge on genomics, followed by lay civilians, university students, lawyers and legislators. Biomedical researchers is the group with less anxiety. Fisher's homogeneity test gives a significant variance among the groups in total anxiety $(>95 \%)$ so that there are significant differences among the groups in the anxiety generated by genomic issues. Mutilation, guilt and shame anxieties present the greatest levels. Mutilation is associated mainly with the fear of being subjected to genetic manipulations which will affect health. Guilt is associated mainly to moral disagreement towards certain forms of genetic manipulation such as cloning or eugenics. Shame refers mainly to lack of knowledge about genetic research and to personal private information which should not be shared by others, but is not explicitly disapproved.

Figure 2 presents levels of hostility using the Gottschalk and Gleser method. The outer covered hostility is most present in lawyers and legislators associated with aggressive behaviour occurring in solving litigations and in their worries for genetic discrimination. Lay retired civilians present the greatest level of inner hostility towards themselves because of feeling not worthy and ambivalent hostility of others to them because of feeling being discriminated or disrespected by others, probably associated to their situation of lack of social support in general in Latin America for which they feel discriminated and they lack self esteem. There is significant difference in variance among the groups ( $>95 \%)$ using the Fisher's homogeneity test so that there are significant differences among the groups in the level of hostility felt being generated by genomic issues.

\section{DISCUSSION: SOCIAL, LEGAL AND ETHICAL CONSEQUENCES}

The application of genomic research can have social, legal and ethical consequences, both in personal and familial spheres and also in broader collective spheres which can affect societies and communities.

\section{Personal and familiar issues}


Table 3. Perceived effects of transgenic use.

\begin{tabular}{|c|c|c|c|c|c|c|}
\hline Issue & $\begin{array}{l}\text { Lawyers } \\
(n=13)\end{array}$ & $\begin{array}{c}\text { Legal } \\
\text { articles } \\
(n=7)\end{array}$ & $\begin{array}{c}\text { Lay } \\
\text { Civilians } \\
\qquad(n=76)\end{array}$ & $\begin{array}{l}\text { Students } \\
\qquad(n=77)\end{array}$ & $\begin{array}{l}\text { Scientists } \\
\qquad(n=19)\end{array}$ & $\begin{array}{l}\text { Biomedical } \\
\text { articles } \\
(n=16)\end{array}$ \\
\hline Enhancement Production \% & 54 & 28 & 11 & 29 & 53 & 37 \\
\hline Enhancement Properties \% & 8 & 28 & 17 & 27 & 28 & 37 \\
\hline Plague Resistance \% & 0 & 0 & 7 & 8 & 26 & 6 \\
\hline Cancer \% & 0 & 0 & 4 & 10 & 0 & 0 \\
\hline $\begin{array}{l}\text { Ecological Equilibrium Alteration } \\
\%\end{array}$ & 31 & 14 & 4 & 4 & 32 & 29 \\
\hline Biodiversity diminution $\%$ & 0 & 0 & 1 & 0 & 11 & 6 \\
\hline Commercialization \% & 38 & 43 & 3 & 1 & 11 & 29 \\
\hline Health Damage \% & 31 & 0 & 41 & 43 & 0 & 0 \\
\hline Artificial \% & 8 & 0 & 25 & 18 & 0 & 0 \\
\hline Problems Biosecurity \% & 0 & 0 & 1 & 0 & 11 & 6 \\
\hline Regulation Necessity \% & 46 & 57 & 3 & 1 & 16 & 6 \\
\hline
\end{tabular}

It is expected that knowledge of the human genome will offer new ways for prevention, diagnosis and treatment of diseases with a hereditary component. There are many possible advances in genomic medicine[i]. However, presently there are no preventive or safe therapeutic measures for most hereditary diseases in contrast with the development of diagnostic and predictive capacity of genetic probes. This raises the issue that some genetic information may be unwanted for some individuals since it will generate unnecessary anxiety due to lack of preventive or therapeutic solutions.

Genetic modifications in general carry greater risks than benefits. For example, with respect to somatic gene therapy, there is a high risk associated to the intervention so that it is recommended only for serious diseases without cure. Among the risks pointed out are: interference with normal genes, induction of cancer, short time activity of genes introduced, induction of mutations and viral infections (Austin-Ward and Villaseca, 1998). Caution is expressed for genetic modifications in the germ line, be it for therapeutic reasons or for enhancement, since it may alter the integrity of human genetic patrimony by introducing undesired alterations and because of lack of consent for future generations (Austin-Ward and Villaseca, 1998; Giorgiutti, 1998; Cruz-Coke, 1999). On the other hand, if the technique is perfected it might be beneficial in helping to eradicate diseases for future and present generations (Rodríguez, 2003; Valenzuela, 2003). Genetic modifications leading to enhancement is viewed as non ethical since their use in the present cultural circumstances will aggravate social differences due to their restricted access to those who can afford it.

Even though genomic research and its applications is positively perceived by some stakeholders, it is recognized that there are genetic manipulations contrary to human dignity and fundamental human rights, demanding regulation through legal norms and sanctions. For example, human reproductive cloning is, in general, negatively perceived by many different agents who want to regulate, criminalize and penalize it (Saez, 2000) On the contrary, human therapeutic cloning (the use of clones for culturing embryonic stem cells and posterior organ transplantation) received a better judgment by some scientists, but their critics indicate that this technique manipulates human beings by using them just as source of organs.

Another topic refers to the privacy of genetic data since this information can be used as an instrument of power by third parties (Bergel, 2002). The protection of genetic information implies that only the person from whom it is derived can authorize the use. The principle of autonomy must prevail unless there is a criminal cause or risk of damage to others, in which case a court order can overrule the confidentiality of the data. Informed consent is required 
for any genetic test. They need to establish clearly who will have access to the information and which will be the uses of the sample taken, including possible future research.

Among the negative consequences of lack of privacy is the possibility of genetic discrimination, particularly in the area of health insurance and employment. There is concern that employers may avoid hiring workers with particular diseases based on genetic tests (Kurczyn, 2002) or that insurers may establish their fees based on the results of genetic tests (Alvarez, 2002; Badillo, 2002). However, the reality in Latin America is that currently there are no court cases due to genetic discrimination and there is no danger of adverse selection in Latina America with respect to the customer knowing more than the insurance company, since practically the only reliable genetic tests are for monogenic diseases of low frequency in the population. Nevertheless, legislators suggest to regulate against employers and insurers requiring genetic tests (Arriberre, 2000).

Confidentiality obliges to keep secret genetic data as UNESCO Universal Declaration on the Human Genome and Human Rights observes (section B, article 7). For safeguarding confidentiality it is recommended that genetic data be kept separated from medical records until security systems are developed (Zanlungo et al. 1999). The individual genetic information posses peculiar characteristics as it may be partially shared by family members, race or ethnic group. There is a risk associated with the divulgation of genetic information due to the possibility of social stigmatization and genetic discrimination as we just explained in the previous paragraph. In Latin American countries there is no regulation for the process of collecting genetic data or medical records, so that the privacy of genetic information is not protected. Regulation is needed to prescribe the way for obtaining genetic information, including informed consent and sanctions for inadequate disclosure of information, establishing as well exceptions for invading privacy, (for example, criminal liability by court request) (Kuyumdjian, 2000). Another important aspect of confidentiality of genetic data refers to, on the one hand patients "right to know" which involves accessing to all genetic information referring to one's health and on the other hand, the "right to ignore" especially when there is no treatment or preventive measures for a particular disease, as it may generate unnecessary anxiety (Kuyumdjian, 2000). The decision to know or to ignore belongs to each patient.

\section{Collective issues}

Biomedical researches, lawyers and legislators in Latin America worry about the commercial mentality associated with genetic research and to the fact that it may lead to increase the gap already existing between developed and underdeveloped countries. There are also objections to the commercialization of genetically modified organisms, since the tendency is to use the genetic richness of Latin American natural products for patenting new organisms in developed countries. This can have negative effects on Latin America since those same patents can then be used to restrict access and change farming practices in Latin America. A relevant example to illustrate those negative effects is the Canadian dispute that took place between Monsanto and the farmer Schmeiser. Percy Schmeiser is a farmer from Canada whose Canola fields were contaminated with Monsanto's Round-Up Ready Canola. Monsanto's position was that it doesn't matter whether Schmeiser knew or not that his canola field was contaminated with the Roundup Ready gene but that he must pay their technology fee. Monsanto took Percy Schmeiser to court. The U.S. agrochemical company giant said Schmeiser was growing the company's genetically modified canola without permission, and without paying for the right to do so. The Canadian Supreme Court ruled that Monsanto's patent was valid, but Schmeiser did not have to pay Monsanto's technology fee. "The Supreme Court ruled Monsanto owns and controls the gene, so the liability issue now follows the flow of the gene," For Schmeiser. "Monsanto is totally liable for contamination and pollution of anybody's field according to this line of reasoning", but Monsanto continues abusing of U.S. patent law to control the usage of staple crop seeds by farmers (http://www.percyschmeiser.com/). This raises the issue of the danger of excessive control by biotechnological companies and when there is no regulation the rapid spread of genetically modified organisms among farmers since these would be preferred over traditional crops due to their special properties, such as greater vigour and resistance to insects or to bacterial infections, which at large could affect biodiversity. It is argued that biotechnological companies use genetic material from Latin American countries to create genetically modified organisms and commercialize them without financial gain for these countries.

There are worries about the possible effect of a decrease in biodiversity because of the use of genetically modified organisms in agriculture. An example is what is happening in Argentine, where the agricultural production system has become dominated by one crop: the transgenic Roundup Ready soybean developed by Monsanto. This crop is resistant to the herbicide glyphosate and relies on repeated herbicide applications to control weeds. But Nature finds ways to evolve around it. Already, strains of Roundupresistant weeds have appeared in Argentine, requiring everheavier doses of the herbicide, killing off microbes and degrading soil quality. Heavy herbicide applications and widespread planting of Roundup Ready soybeans has also led to increases in pest and disease severity. The rate at which forests in Northern Argentina are being turned into soy plantations is 3-6 times higher than the world average. This massive destruction of forests has sparked violence and protests by agrarian families and is changing the local climate to a semi-desert causing both droughts and flooding (http://apis.ufl.edu). Monoculture makes a country very vulnerable to environmental changes. 
Another important point is that part of the advocacy done by environmentalist groups and the fears expressed by the civil society are focused on arguments that are not always scientifically sound. The idea of rejecting genetically modified organisms because of being artificial or that human beings act against sacred laws of Nature by introducing genetic modifications can not be sustained. Following this ideology we could not consume most of world's cattle and crops production, since human beings have manipulated animal and plant genomes for many centuries forming hybrids, inducing mutations and selecting varieties artificially. In a poll carried out by FAO in Latin America, it was found that civilians have a negative perception on transgenic food due to lack of knowledge on how they are generated, lack of confidence toward biotechnological international companies, fear to unknown innovations, lack of confidence toward regulatory measures and the threat to biodiversity (http://www.ric.fao.org/redes/redbio/default.htm).

Countries look for safeguards to avoid the commercialization of unsafe crops. In Montreal, in January 2000 a biosecurity protocol has been signed up for ruling transgenic world trade so that any country has the right to deny the commercialization of certain transgenics if there is reasonable scientific evidence to health risk or environmental damage. Nevertheless, it is not clear if these rights will enter into conflict to the free market defended by the World Trade Organization.

However, there are very few studies which show possible toxic risks or adverse effects on health because of consuming transgenic food (Roig and Gomez, 2000). Some of the potential adverse effects identified are: allergy, resistance to antibiotics, lack or modification of the nutritious value of food, presence of toxic components, emergence of new non treatable diseases and possible damage to wild species (Reyes and Rozowski, 2003; Paparini and Romano-Soica, 2004). There is, therefore, an ethical exigency for guaranteeing test trials for every transgenic introduced in the market.

With respect to human genes patenting the legal, ethical and intellectual legitimacy are at the centre of many debates (Madrid, 1999). Bergel (2000) argues that the current tendency to patent human gene sequences has derived in the progressive loss of limits between invention and discovery, and is opposed to the principle of non commercialization of the body and its parts. In this regard, the practice of commercializing the human genome is contrary to the 1997 UNESCO Universal Declaration on the Human Genome and Human Rights (1997), which considers that "the human genome in its natural state can not give rise to pecuniary benefit". Patenting gene sequences without knowing its function or utility can hamper the creativity of other researches who could have use those broadly patented sequences to pursue crucial research projects Bergel considers that this practice damages human dignity since it manipulates human genetic information with commercial interests while others agree with patenting of human genes on the basis that it can further innovation (Bergel, 2002). The countries which possess the technology and are governed by a comprehensive patent system control and dominate the market (appropriating unethically an information that is shared by all human beings. The initial plan of the Human Genome Project Consortium was to generate genetic data with free world access avoiding competition which would restrict access to information and would made human genes enter into the patent system and genetic tests a big business. Unfortunately, the intrusion of Celera Genomics in

Table 4. Perceived participation as genomic research subject.

\begin{tabular}{|c|c|c|c|c|}
\hline Issue & $\begin{array}{c}\text { Lawyers } \\
(n=58)\end{array}$ & Lay civilians $(n=76)$ & Students $(n=77)$ & Scientists $(n=74)$ \\
\hline Treatment \% & 81 & 46 & 69 & 54 \\
\hline Enhancement \% & 2 & 8 & 13 & 41 \\
\hline Science Advancement \% & 0 & 5 & 3 & 20 \\
\hline Guinea Pig \% & 14 & 12 & 14 & 4 \\
\hline Lack of being tested $\%$ & 10 & 1 & 5 & 23 \\
\hline Against Nature \% & 2 & 11 & 3 & 0 \\
\hline Fear to the unknown \% & 4 & 13 & 1 & 0 \\
\hline Acceptance of oneself $\%$ & 28 & 20 & 44 & 23 \\
\hline Fear to health damage $\%$ & 28 & 28 & 25 & 9 \\
\hline
\end{tabular}


generating the whole human genome sequence and the interest of Biotechnological companies in generating patents has prevail and the breach between developed and developing countries is increasing because of biotechnology.

\section{CONCLUDING REMARKS}

It is recognized that the human genome is a juridical good that must be protected, therefore, regulatory norms are necessary for genomic research and genetic practices (Madrid, 1999; Arriberre, 2000). To this end, bioethics has a role in clarifying the complex topics of social consequences of access to genetic information. Clearly, lack of knowledge and reflection creates anxiety as is shown in this study. Therefore it will be helpful to improve information about these issues in a critical way at all levels of society.

Nevertheless, in Latin America there is presently no interest in conducting research on human genetic enhancement or in human reproductive cloning. But there is need for legal regulation in order to control the possibility of arbitrary genetic manipulations contrary to human dignity. There are very few regulations related to genomic research and its applications in Latin American countries. There is little regulation of the introduction of genetically modified organisms (GMOs); some GMOs are still under evaluation for safety and nevertheless they are introduced as if their safety was established. There are issues which should be regulated, such as the protection of biodiversity or introducing genes from one species to others with properties not wanted in wild plants such as resistance to herbicides or to insects or microorganisms.

\section{REFERENCES}

ALVAREZ, Rosa María. El Contrato del Seguro y el Proyecto del Genoma Humano. Cuadernos del Núcleo de Estudios Interdisciplinarios en Salud y Derechos Humanos. Diagnóstico Genético y Derechos Humanos, UNAM, 2002, vol. 3. ISBN 968-36-6693-0. Available from Internet: http://info.juridicas.unam.mx/publica/salud/cuad3/alvarez.h tm.

ARRIBERRE, Roberto. El Deber de Información y la Confidencialidad en la Genética. Aportes para una Legislación que Preserve la Intimidad de la Persona y Evite la Discriminación. In: Jornadas Nacionales de Bioética y Derecho. (1 ${ }^{\circ}, 22$ - 23 August, 2000, Buenos Aires, Argentina). Asociación de Abogados de Buenos Aires. 2000. Available from Internet: http://www.aaba.org.ar/bi170p24.htm.

AUSTIN-WARD, Enrique Daniel and VILLASECA G., Cecilia. La terapia génica y sus aplicaciones. Revista Médica de Chile, 1998, vol. 126, no. 7, p. 838-845.

BADILLO Alonso, María Elisa. Seguros y Discriminación con Bases Genéticas. Cuadernos del Núcleo de Estudios
Interdisciplinarios en Salud y Derechos Humanos. Diagnóstico Genético y Derechos Humanos, UNAM, 2002, vol. 3. ISBN 968-36-6693-0. Available from Internet:http://info.juridicas.unam.mx/publica/salud/cuad3/ badi.htm.

BERGEL, S.D. Aspectos Éticos y Jurídicos del Proyecto Genoma Humano: Patentamiento de Genes y Secuencias. Medicina (Buenos Aires), 2000, vol. 60, no. 4, p. 729-730.

BERGEL, S.D. Los Derechos Humanos entre la Bioética y la Genética. Acta Bioethica, 2002, vol. 8, no. 2, p. 315-329.

CRUZ-COKE, R. Historia de la genética latinoamericana en el siglo XX. Revista Médica de Chile, 1999, vol. 127, no. 12 , p. 1524-1532.

ROIG, J.L.D. and Gómez, Mercedes. Riesgos sobre la Salud de los Alimentos Modificados Genéticamente: Una revisión bibliográfica. Revista Española de Salud Pública, 2000, vol. 74, no. 3. p. 255-261.

GIORGIUTTI, Elba D. Aspectos éticos de la terapia génica. Medicina (Buenos Aires), 1998, vol. 58, no. 2, p. 228-238.

GOTTSCHALK, L. and LOLAS F. The Gottschalk-Gleser Content Analysis Method of Measuring the Magnitude of Psychological Dimensions: Its Application in Transcultural Research. Transcultural Psychiatric Research Review, 1989, vol. 26, no. 1, p. 83-111.

KUYUMDJIAN, P. Proyecto del Genoma Humano y Derecho a la Intimidad. In: Jornadas Nacionales de Bioética y Derecho. (1º, 22 - 23 August, 2000, Buenos Aires, Argentina). Asociación de Abogados de Buenos Aires. 2000. Available from: Internet: http://www.aaba.org.ar/bi170p23.htm.

KURCZYN, P.V. Proyecto del Genoma Humano y las Relaciones Laborales.Cuadernos del Núcleo de Estudios Interdisciplinarios en Salud y Derechos Humanos. Diagnóstico Genético y Derechos Humanos, UNAM, 2002, vol. 3. ISBN 968-36-6693-0. Available from Internet: http://info.juridicas.unam.mx/publica/salud/cuad3/kurczyn. htm.

LOLAS, Stepke, Fernando; VALDEBENITO Herrera, Carolina and RODRIGUEZ Yunta, Eduardo. El Proyecto del Genoma Humano en la Literatura Biomédica en cuatro países Latinoamericanos. Acta Bioethica, 2004, vol. 10, no. 2, p. $167-180$.

MADRID, R. III. Cuestiones Jurídicas. En: Proyecto del Genoma Humano: Presente y Perspectivas Futuras, Humanitas, 1999, vol. 15, p. 20-24.

PAPARINI, A. and ROMANO-SOICA, V. Public Health Issues Related with the Consumption of Food Obtained 
from Genetically Modified Organisms. Biotechnology Annual Review, 2004, vol. 10, no. 1, p. 85-122.

REYES, M.S. and ROZOWSKI, J.N. Alimentos Transgénicos. Revista Chilena de Nutrición, 2003, vol. 30,no. 1, p. 21-26.

RODRIGUEZ, Y., Eduardo. Terapia génica y principios éticos. Acta Bioethica, 2003, vol. 9, no. 1, p. 69-79.

SAEZ, Capel, José. Es de Total Necesidad Tipificar Penalmente los Actos Relativos a la Manipulación Genética con el Fin de Clonar Seres Humanos. In: Jornadas Nacionales de Bioética y Derecho. (1으. 22 - 23 August, 2000, Buenos Aires, Argentina). Asociación de Abogados de Buenos Aires. 2000. Available from: Internet: http://www.aaba.org.ar/bi170p32.htm.

VALENZUELA, C.Y. Ética científica de la terapia génica de individuos. Urgencia de la cirugía génica del AND. Revista Médica de Chile, 2003, vol. 131, no. 1, p. 12081214.

ZANLUNGO M., Silvana; ARRESE J., Marco and RIGOTTI R., Attilio. Medicina molecular: presente y futuro. Revista Médica de Chile, 1999, vol. 127, no. 8, p. 982-988.

[i] Such as: new vaccines with moderate inmunogenicity for hepatitis and malaria; molecules obtained by genetic manipulation, such as insulin, growth hormone and interferon; development of molecular neurobiology for treatment of psychiatric diseases; production of tissue activators such as t-PA; production of monoclonal antibodies; molecular diagnosis using micro-arrays; pharmacogenetics or therapy based on the individual genetic characteristics of the person with respect to respond to drugs; molecular epidemiology to known risk factors, geographic distribution of diseases and prevention; new therapeutic interventions using genetic engineering: gene therapy, introduction of genes which activate drugs for destruction of cancer cells, stimulation of the immune response, inactivation of mutant oncogenes, activation of tumor suppressor genes, rybozimes or RNA with catalytic activity for destroying specific proteins, antisense therapy; and paternity tests. 